\title{
Oxidation of Cysteinate Anions Immobilized in the Interlamellar Space of CaAl-Layered Double Hydroxide
}

\author{
Zita Timár ${ }^{1,2}$, Truong Ngoc Hung ${ }^{1,2}$, Cora Pravda ${ }^{3}$, Zoltán Kónya ${ }^{3,4}$ (D) Ákos Kukovecz ${ }^{3}$, Pál Sipos ${ }^{1,5, *}$, \\ Gábor Varga ${ }^{1,6, *(\mathbb{D})}$ and István Pálinkó ${ }^{1,2}$ (D)
}

1 Materials and Solution Structure Research Group and Interdisciplinary Excellence Centre, Institute of Chemistry, University of Szeged, Aradi Vértanúk tere 1, H-6720 Szeged, Hungary; zita.timar92@chem.u-szeged.hu (Z.T.); thuanhung1987@gmail.com (T.N.H.); palinko@chem.u-szeged.hu (I.P.)

2 Department of Organic Chemistry, University of Szeged, Dóm tér 8, H-6720 Szeged, Hungary

3 Department of Applied and Environmental Chemistry, University of Szeged, H-6720 Szeged, Hungary; cora@chem.u-szeged.hu (C.P.); konya@chem.u-szeged.hu (Z.K.); kakos@chem.u-szeged.hu (Á.K.)

4 MTA-SZTE Reaction Kinetics and Surface Chemistry Research Group, H-6720 Szeged, Hungary

5 Department of Inorganic and Analytical Chemistry, University of Szeged, Dóm tér 7, H-6720 Szeged, Hungary

6 Department of Physical Chemistry and Materials Science, University of Szeged, H-6720 Szeged, Hungary

* Correspondence: sipos@chem.u-szeged.hu (P.S.); gabor.varga5@chem.u-szeged.hu (G.V.)

Citation: Timár, Z; Hung, T.N.; Pravda, C.; Kónya, Z.; Kukovecz, Á.; Sipos, P.; Varga, G.; Pálinkó, I. Oxidation of Cysteinate Anions Immobilized in the Interlamellar Space of CaAl-Layered Double Hydroxide. Materials 2021, 14, 1202. https://doi.org/10.3390/ma14051202

Academic Editor: Daniela Iannazzo

Received: 28 January 2021

Accepted: 1 March 2021

Published: 4 March 2021

Publisher's Note: MDPI stays neutral with regard to jurisdictional claims in published maps and institutional affiliations.

Copyright: (c) 2021 by the authors. Licensee MDPI, Basel, Switzerland. This article is an open access article distributed under the terms and conditions of the Creative Commons Attribution (CC BY) license (https:// creativecommons.org/licenses/by/ $4.0 /)$.

\begin{abstract}
L-Cysteinate-intercalated CaAl-layered double hydroxide (LDH) was prepared by the co-precipitation method producing highly crystalline hydrocalumite phase with a well-pillared interlayer gallery. The obtained materials were characterized by X-ray diffractometry, IR as well as Raman spectroscopies. By performing interlamellar oxidation reactions with peracetic acid as oxidant, oxidation of cysteinate to cystinate in aqueous and cysteinate sulfenic acid in acetonic suspensions occurred. The oxidations could be performed under mild conditions, at room temperature, under neutral $\mathrm{pH}$ and in air. It has been shown that the transformation pathways are due to the presence of the layered structure, that is, the confined space of the LDH behaved as molecular reactor.
\end{abstract}

Keywords: cysteine oxo acids; cysteinate oxidation to cystinate; cysteinate anion-pillared CaAllayered double hydroxide (LDH); confined space-molecular reactor

\section{Introduction}

Sulfur-containing organic compounds-especially cysteine and its derivatives-as bioactive ingredients or functional bioconjugates have been widely applied in chemoenzymatic syntheses as well as composing biomedicines for many years [1-3]. Numerous previous studies demonstrated considerable improvement in the biocatalytic activity of living and artificial enzymes containing thiol- and/or disulfide-containing redox moieties [4-6]. Additionally, biomimetic compounds modelled after natural enzymes including cystine side chains proved to be efficient biosensors and serodiagnostic test molecules as well as catalysts in fermentation applications [7-11]. The oxo acid forms of cysteine also play significant roles as medicines or nucleophilic partners in enantioselective reactions from, for instance, nitrile synthesis to the treatment of plantar hyperkeratosis or acne [12-15].

Unfortunately, in spite of these useful applications, aiming the production of these derivatives through the oxidation of cysteine remains synthetic challenge because of the numerous feasible reaction pathways and possible side products [16,17]. It has been shown that transformations of cysteine and cysteine-related molecules towards various products can be achieved via the development of catalytic reaction systems and/or exploiting the interlayer gallery of layered materials are needed [18-22].

The challenge of widening the palette of ways for the lab-scale oxidative transformations of cysteine motivated our work. The idea was to anchor the anionic form of cysteine among the layers of CaAl-LDH (hydrocalumite) and probe various oxidizing agents. This 
combination has never been tried before. In the followings, it is shown that by tuning the reaction conditions and altering the solvent, influencing the transformation pathways in a beneficial way became possible.

\section{Materials and Methods}

\subsection{Materials}

L-cysteine, $\mathrm{Ca}\left(\mathrm{NO}_{3}\right)_{2} \times 4 \mathrm{H}_{2} \mathrm{O}, \mathrm{Al}\left(\mathrm{NO}_{3}\right)_{3} \times 9 \mathrm{H}_{2} \mathrm{O}, \mathrm{NaOH}$, peracetic acid, bromine, hydrogen peroxide, methanol and acetone were purchased from Sigma Aldrich (Budapest, Hungary) and were used without further purification.

\subsection{Synthesis of Nitrate-Containing and L-Cysteinate-Intercalated CaAl-LDH}

A modified co-precipitation method was used for the synthesis and the intercalation process. Firstly, the organic compounds (most often $6.0 \times 10^{-3} \mathrm{~mol}$, but $1.2 \times 10^{-2}$ or $1.8 \times 10^{-2}$ mol were also used) were dissolved in $65 \mathrm{~cm}^{3}$ of methanol, then $100 \mathrm{~cm}^{3}$ of aqueous solution containing $\mathrm{Ca}\left(\mathrm{NO}_{3}\right)_{2} \times 4 \mathrm{H}_{2} \mathrm{O}(0.3 \mathrm{M})$ and $\mathrm{Al}\left(\mathrm{NO}_{3}\right)_{3} \times 9 \mathrm{H}_{2} \mathrm{O}(0.15 \mathrm{M})$ was added, and the $\mathrm{pH}$ of 13.1 was set with $\mathrm{NaOH}$ solution $(3 \mathrm{M})$. The mixture was stirred at $65{ }^{\circ} \mathrm{C}$ for 3 days. Then the suspension was filtered, washed with water and methanol several times and dried at $85{ }^{\circ} \mathrm{C}$ overnight. Nitrate-containing LDH (layered double hydroxide) was produced in the same way without adding organic phase to the slurry. All operations were performed under nitrogen atmosphere to minimize carbonate intercalation from the airborne $\mathrm{CO}_{2}$.

\subsection{Interlayer Oxidation of L-Cysteinate}

During the oxidation process, the oxidizing agent (peracetic acid, bromine or hydrogen peroxide) was applied in various concentrations (from $0.4 \mathrm{M}$ to $0.7 \mathrm{M}$ ) adding them dropwise to the suspensions containing the intercalated LDH suspended in water, methanol or acetone $\left(100 \mathrm{~cm}^{3}\right)$. The suspensions were stirred for $60 \mathrm{~min}$, then they were filtered and dried at $353 \mathrm{~K}$. The amount of the intercalated LDH $(0.1 \mathrm{~g})$ and the temperature $(298 \mathrm{~K})$ were the same in all cases. The possible reaction pathways are depicted in Scheme 1.

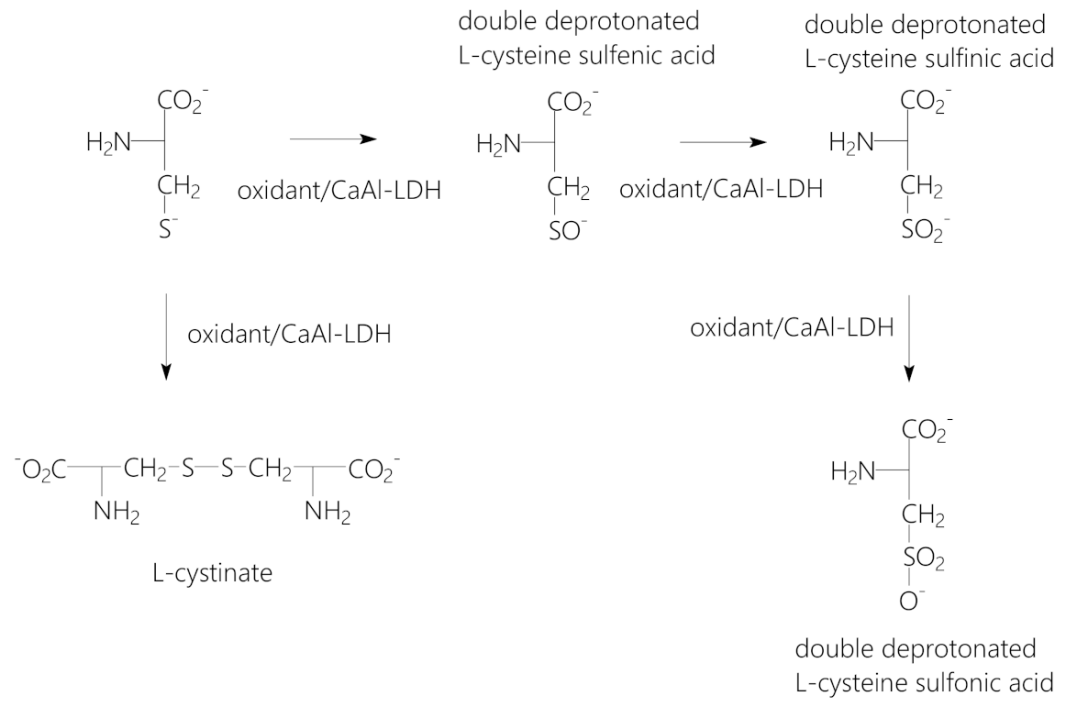

Scheme 1. Possible reaction pathways of L-cysteinate oxidation incorporated in CaAl-LDH.

\subsection{Methods of Structural Characterization}

Powder X-ray patterns were recorded by a Rigaku XRD-6000 diffractometer (Rigaku, Tokyo, Japan) using $\mathrm{CuK} \alpha$ radiation $(\lambda=0.15418 \mathrm{~nm})$ at $40 \mathrm{kV}$ and $30 \mathrm{~mA}$ with $2^{\circ} / \mathrm{min}$ scan speed.

The instrument for recording the IR spectra was a Bruker Vertex 70 spectrophotometer (Bruker, Billerica, MA, USA) equipped with a single reflection diamond ATR accessory 
(Bruker, Billerica, MA, USA). Spectra were recorded in the $4000-400 \mathrm{~cm}^{-1}$ wavenumber range, but only the most informative wavenumber ranges will be displayed and discussed in the paper. 256 scans were collected for each spectrum, and the resolution was $4 \mathrm{~cm}^{-1}$.

Raman spectra were recorded with a Raman Senterra II (Bruker) microscope (Bruker, Billerica, MA, USA) at an excitation wavelength of $765 \mathrm{~nm}$ applying $12.5 \mathrm{~mW}$ laser power and averaging 20 spectra with an exposition time of $20 \mathrm{~s}$.

UV/Vis spectroscopy was used for the quantitative analysis of L-cysteine at the wavelength of $231 \mathrm{~nm}$. The members of the calibration series as well as the unknown samples were measured on a Shimadzu UV-1650 spectrophotometer (Shimadzu, Kyoto, Japan).

\section{Results and Discussions}

After preparing CaAl-LDH in the well-known co-precipitation synthesis route, through combining previously published intercalation methods [21-23], cysteinate anions were immobilized in the interlayer gallery of hydrocalumite (CaAl-LDH). The success of this operation was verified by X-ray diffraction (XRD) measurements (Figure 1A) and the incorporated amount was $8 \times 10^{-5} \mathrm{~mol}$. Both the as-prepared and intercalated structures exhibited diffraction patterns corresponding to lamellar monoclinic structure in $\mathrm{P} 2{ }_{1}$ space group being analogous to that of a nitrate-containing CaAl-LDH (JCPDS database: PDF \#89-6723). Furthermore, the (001) and the other diffraction lines of intercalated hydrocalumite shifted to smaller angles compared to those of the as-prepared one indicating the expansion of basal spacing from $0.757 \mathrm{~nm}$ to $0.864 \mathrm{~nm}$ associated with altering the anions in the interlayer space. The extent of the expansion corresponds to single-layer insertion of the cysteinate anions, which is in good agreement with previous reports [21-23].

The as-prepared LDH and the intercalated composite were studied by IR as well as Raman spectroscopies (Figure 1B,C).

The band due to the $v 3$ (asymmetric stretching) mode of nitrate anions at $1355 \mathrm{~cm}^{-1}$ could be seen in IR spectrum of the as-prepared LDH along with $v 3$ vibration band of surface-adsorbed carbonate $\left(1405 \mathrm{~cm}^{-1}\right)$ and $\beta(\mathrm{OH})$ vibration band $\left(1650 \mathrm{~cm}^{-1}\right)$ as well as the characteristic vibration band identified as the stretching vibration mode of $\mathrm{Al}-\mathrm{O}$ bond $\left(779 \mathrm{~cm}^{-1}\right)$ [24]. The IR spectrum of the composite material exhibited bands characteristic of an LDH with intercalated carboxylate anions [25,26]. Accordingly, fingerprint-like vibration modes of the carboxylate group appeared, the asymmetric vibrations bands at $\sim 1600$ and $1569 \mathrm{~cm}^{-1}$ and the symmetric one at $\sim 1433 \mathrm{~cm}^{-1}$. In accordance with literature data, doubling of $v_{\mathrm{as}}\left(\mathrm{COO}^{-}\right)$vibration suggested that cysteinate anions were linked to the layers as syn-anti carboxylate bridges with bidentate carboxylate coordination [27]. During intercalation, partial anion exchange only occurred indicated by the "survival" of peaks attributed to carbonate and nitrate ions. In view of the absence of the significant changes in the IR spectra, the smallest amount of cysteinate $\left(6.0 \times 10^{-3} \mathrm{~mol}\right.$ to $0.1 \mathrm{~g}$ of LDH) was adequate for achieving the maximum extent of ion exchange. (Figure 1D). 

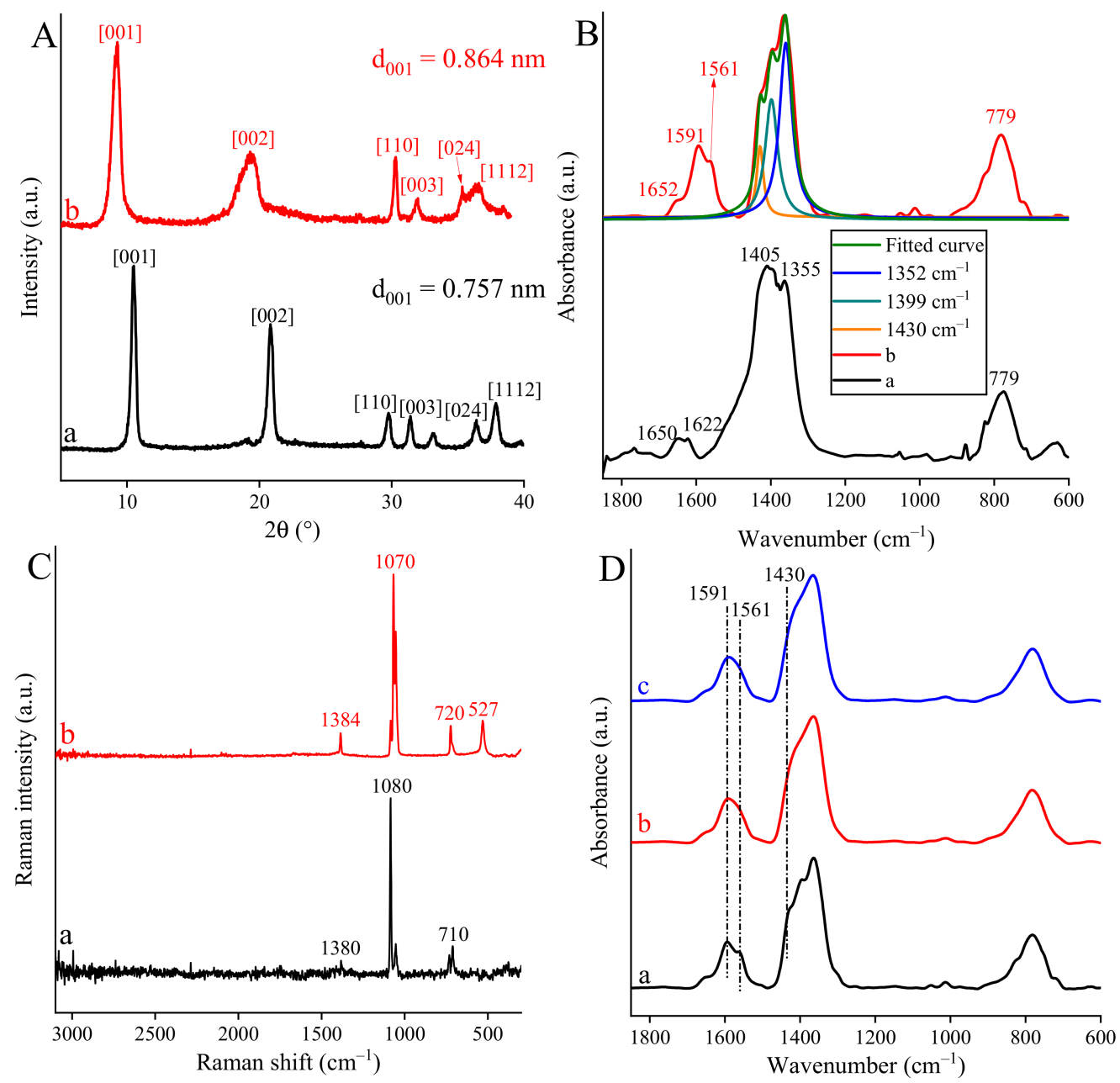

Figure 1. X-ray diffraction (XRD) patterns (A), IR (B) and Raman (C) spectra of $\mathrm{CaAl}-\mathrm{NO}_{3}{ }^{-}-\mathrm{LDH}$ (a) and CaAl-cysteinate-LDH (b). IR spectra (D) of CaAl-cysteinate-LDH $(0.1 \mathrm{~g})$ using $6.0 \times 10^{-3} \mathrm{~mol}$ (a), $1.2 \times 10^{-2} \mathrm{~mol}$ (b) or $1.8 \times 10^{-2} \mathrm{~mol}$ (c) intercalant.

On one hand, Raman spectra also indicated partial intercalation, as the characteristic Raman bands of nitrate/carbonate ions ( 1380, 1070-1080, 710-720 cm $\left.{ }^{-1}\right)$, were not eliminated. On the other hand, the appearance of a S-C stretching band $\left(527 \mathrm{~cm}^{-1}\right)$ evidenced the presence cysteinate anions [28]. Additionally, the lack of the intense stretching vibration of sulfhydryl group $\left(\sim 2500 \mathrm{~cm}^{-1}\right)$ directly demonstrated that thiol groups were deprotonated during the intercalation facilitating the charge neutrality of the composite materials.

In order to efficiently select a suitable reactant for the interlayer oxidation of the cysteinate ions for more detailed studies, scouting experiments were performed using peracetic acid, bromine or $\mathrm{H}_{2} \mathrm{O}_{2}$ at $298 \mathrm{~K}$ using water as solvent. The XRD patterns (Figure 2A) attested that both bromine and hydrogen peroxide damaged the layered structure, which resulted in uncontrollable product distribution. Many products were formed, which was indicated by the IR and Raman spectra (Figure 2B,C) having so many bands that selecting the main products was impossible. The only exception was the case of peracetic acid, which oxidized cysteinate to cystinate, and, although the crystallinity was decreased the LDH reflections could be identified. The formation of cystinate was best highlighted by the intense sharp peak at $454 \mathrm{~cm}^{-1}$ and the less intense at $680 \mathrm{~cm}^{-1}$, assigned to the stretching vibration modes of $C-S$ and S-S bonds, respectively [29]. Additionally, new bands at 1441 and $1595 \mathrm{~cm}^{-1}$ could be detected in the IR spectrum revealing changes in the local environment of the carboxylate groups [30,31]. 

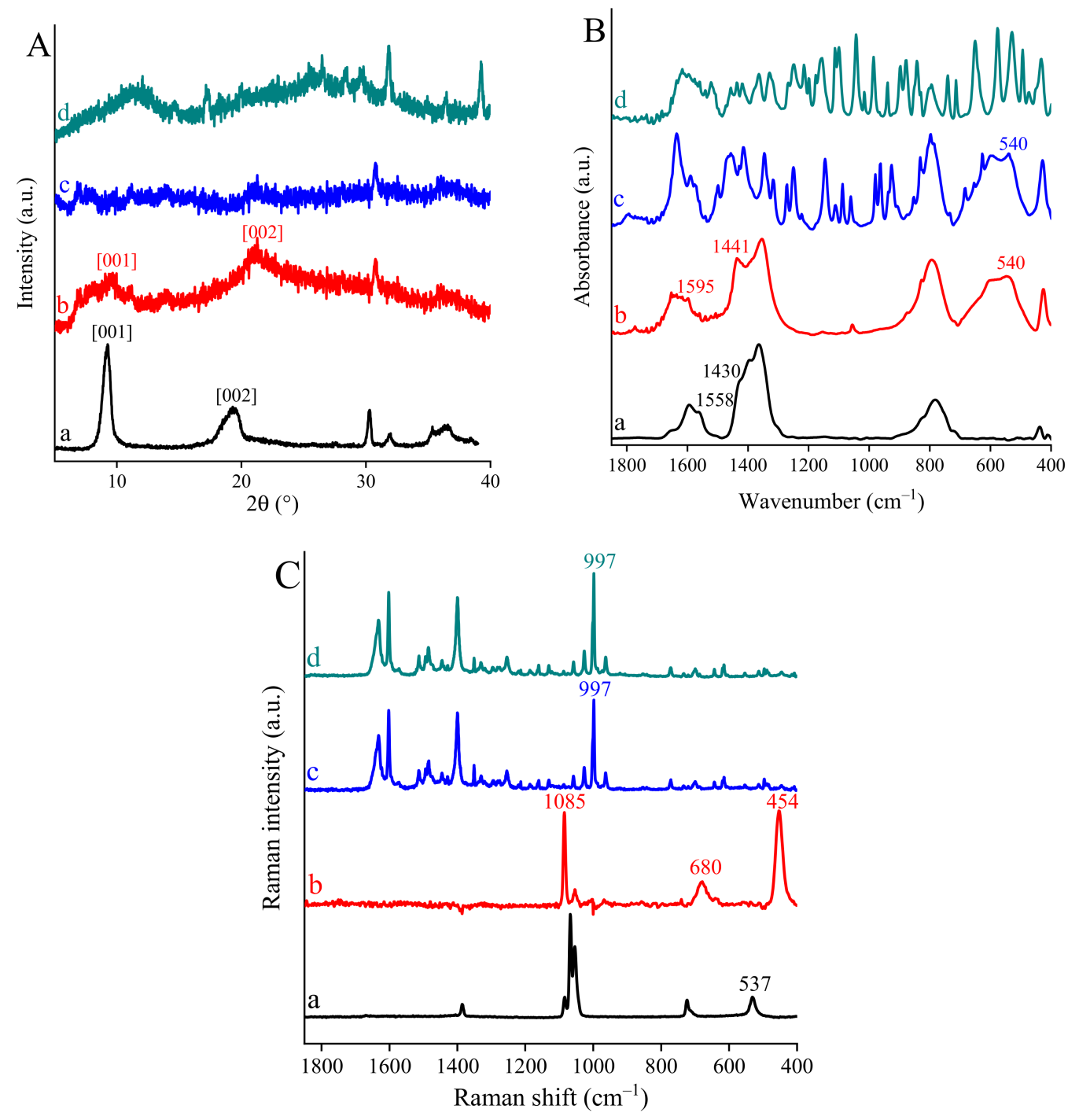

Figure 2. XRD patterns (A), IR (B) and Raman (C) spectra of CaAl-cysteinate-LDH (a) and CaAlcysteinate-LDH $(0.1 \mathrm{~g})$ oxidized by $0.4 \mathrm{M}$ of peracetic acid (b), bromine (c) or $\mathrm{H}_{2} \mathrm{O}_{2}(\mathrm{~d})$ suspended in water $\left(100 \mathrm{~cm}^{3}\right)$ at $298 \mathrm{~K}$. The reaction time was $60 \mathrm{~min}$.

Upon increasing the amount of peracetic acid, the layered structure disappeared indicating the complete collapse of hydrocalumite structure (Figure 3A, traces c and d) leading to uncontrollable product distribution once again (Figure 3B, traces $\mathrm{c}$ and $\mathrm{d}$ ). Clearly, the presence of the layered structure was crucial for the oxidation to occur [32]. 

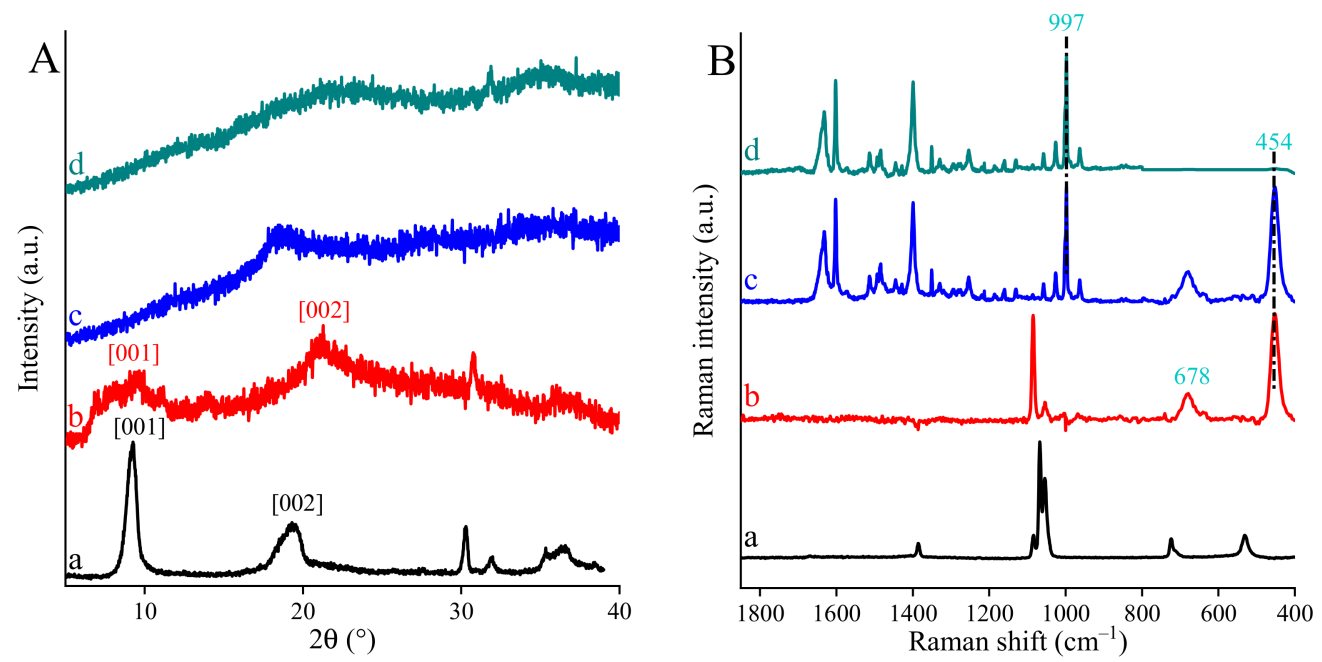

Figure 3. XRD patterns (A) and Raman (B) spectra of CaAl-cysteinate-LDH (a) and CaAl-cysteinateLDH oxidized by peracetic acid; reaction conditions: the oxidizing agent in $0.4 \mathrm{M}$ (b), $0.55 \mathrm{M}$ (c) or $0.70 \mathrm{M}(\mathrm{d})$ concentration was applied to $0.1 \mathrm{~g}$ of composite suspended in $100 \mathrm{~cm}^{3}$ of water at $298 \mathrm{~K}$. The reaction time was $60 \mathrm{~min}$.

On replacing water with organic solvents (acetone or methanol), notable changes in the product distribution were observed. In methanol, the oxidation resulted in significantly lower extent in the degradation of LDH structure than it was experienced in aqueous medium (Figure 4A). On detecting relatively high shift in the characteristic $(00 l)$ reflections, significant decrease in the interlayer space occurred, quite the opposite of the expectations. This finding called our attention to another possible transformation pathway. The IR spectrum of the composite exhibited some strong absorptions over the whole measurement range with bands differing from those of cystinate (Figure $4 \mathrm{~B}$ ). Intense bands in the range of $1600-1400 \mathrm{~cm}^{-1}$ were assigned to antisymmetric and symmetric absorption bands of cysteinate derivatives, while less intense bands centered at $1073 \mathrm{~cm}^{-1}$ could be assigned to the in-plane carboxylic acid $\mathrm{COH}$ bending mode of cysteine sulfonic acid, consistent with previous assignments [33,34]. Furthermore, the band position and intensity of the stretching vibration bands of $\mathrm{C}-\mathrm{S}$ band were changed substantially indicating the formation of one or more cysteine oxo acid forms. On the basis of the observations described above, the formation of oxo acid anion mixture is suggested, the main product being double deprotonated cysteine sulfonic acid anions along with double deprotonated cysteine sulfenic acid anions or, as it was intuitively rather expected, double deprotonated cysteine sulfinic acid anions. Much to our surprise, the Raman spectra of the composite suggested the formation of double deprotonated cysteine sulfenic acid anions without any doubt (Figure $4 \mathrm{C}$ ). The absorption band at $958 \mathrm{~cm}^{-1}$, which increased in intensity in parallel with the increase in the concentration of the oxidant, was associated with the stretching vibration mode of deprotonated $\mathrm{S}-\mathrm{O}(\mathrm{H})$ functional group of cysteine sulfenic acid [35]. Furthermore, there was no evidence that $\mathrm{S}_{-} \mathrm{O}_{2}{ }^{-}$functional group of cysteine sulfinate was produced, this group should have had two intense broad bands in the range of $1250-1000 \mathrm{~cm}^{-1}$ [35]. By performing the oxidation in non-aqueous solvents without the $\mathrm{LDH}$ or dosing it as additive to the solution, it was not possible to produce any of the desired products selectively (Figure 4D). In all cases, both cysteinate and cystinate as well as oxo acid forms were produced. Accordingly, the presence of the layered material providing confined space as molecular reactor with fixed cysteinate ion in it was a contribution of utmost significance in facilitating the oxidation in a beneficial way. 

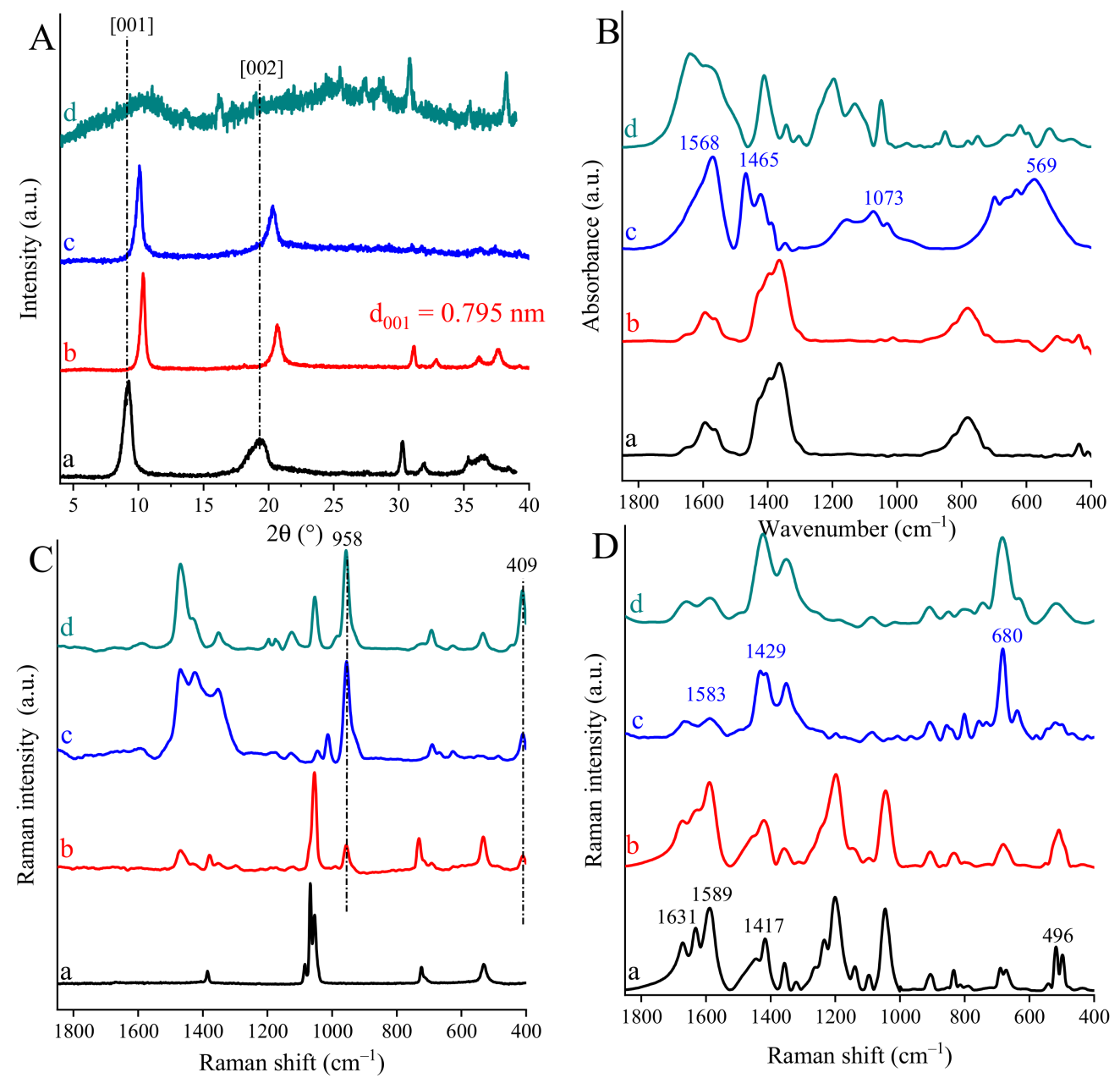

Figure 4. XRD patterns (A), IR (B) and Raman spectra (C) of CaAl-cysteinate-LDH (a) and CaAlcysteinate-LDH $(0.1 \mathrm{~g})$ oxidized by peracetic acid using $0.4 \mathrm{M}(\mathrm{b}), 0.55 \mathrm{M}$ (c) and $0.70 \mathrm{M}(\mathrm{d})$ peracetic acid in methanol $\left(100 \mathrm{~cm}^{3}\right)$. Raman spectra $(\mathbf{D})$ of cysteine $(1 \mathrm{~g})$ oxidized by peracetic acid $(0.4 \mathrm{M})$ in methanol $\left(100 \mathrm{~cm}^{3}\right)$ with (a) or without (b) LDH $(0.1 \mathrm{~g})$ as additive as well as in acetone $\left(100 \mathrm{~cm}^{3}\right)$ with (c) or without (d) LDH $(0.1 \mathrm{~g})$ as additive at $298 \mathrm{~K}$. The reaction time was $60 \mathrm{~min}$.

Finally, by repeating the screening in acetone, a completely different transformation pathway was observed. The ordered structure of LDH was not lost during oxidation, irrespective to the concentration of peracetic acid verified by the XRD patterns (Figure 5A). Moreover, a new LDH phase was developed without eliminating the original one, that is, staging occurred. The interlayer gallery for the new phase was enlarged $(1.154 \mathrm{~nm})$ compared to the cysteinate-containing counterpart $(0.864 \mathrm{~nm})$. Additionally, the ratio of new $\mathrm{LDH}$ phase to the original one grew in line with the increasing amount of added peracetic acid. (It is fair to mention though that a relatively strong and sharp reflection related to unidentified impurity arose at about $25^{\circ}$ of $2 \theta$ values, the intensity of which increased with increasing concentration of peracetic acid. Since the other reflections are assigned to LDH structures, it is reasonable to assume that certain amount of the product formed was released from the interlayer space, and it might be adsorbed on the outer surface of the LDH resulting in the unidentified reflection.). 

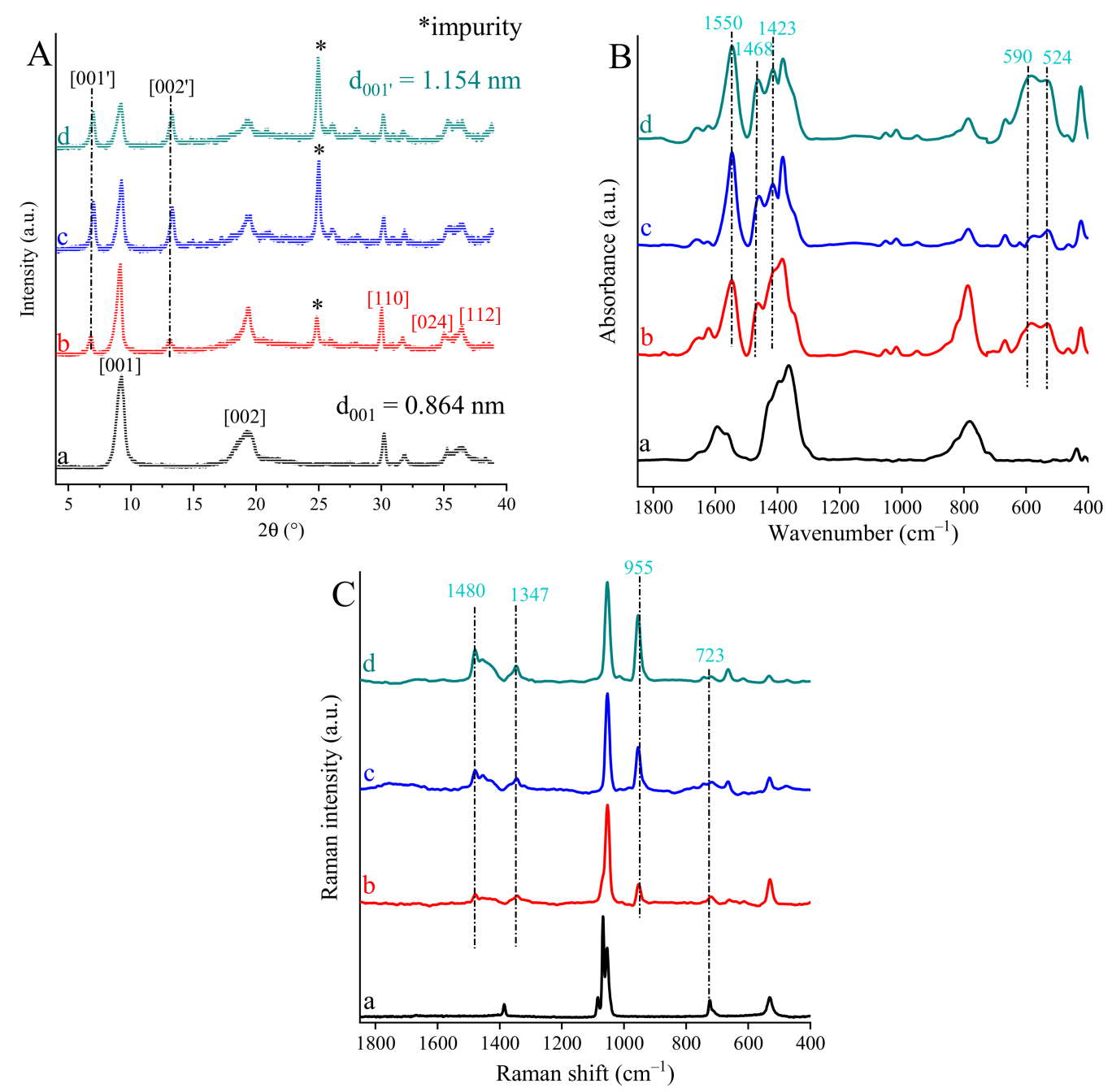

Figure 5. XRD patterns (A), IR (B) and Raman spectra (C) of CaAl-cysteinate-LDH (a) and CaAlcysteinate-LDH (0.1 g) oxidized by peracetic acid upon using $0.4 \mathrm{M}(\mathrm{b}), 0.55 \mathrm{M}$ (c) and $0.65 \mathrm{M}(\mathrm{d})$ peracetic acid in acetone $\left(100 \mathrm{~cm}^{3}\right)$ at $298 \mathrm{~K}$.

A series of absorption bands in IR spectra appeared at 1550, 1468, 1423 and 590 as well as $524 \mathrm{~cm}^{-1}$, they could be clearly attributed to the characteristic vibration modes of cysteine sulfenic acid [33]. Distinct strong absorbances in the high-energy region $\left(1620-1420 \mathrm{~cm}^{-1}\right)$ agreed well with the antisymmetric and symmetric vibration modes of carboxylate group overlapped with vibrations of sulfenyl group, while less intense bands at about $550 \mathrm{~cm}^{-1}$ could be related to the deformation mode vibrations of C-S bond. No evidence for the formation of cysteine sulfinate were found. Including strong peaks at 955, 1347 and $1480 \mathrm{~cm}^{-1}$ identified as stretching vibration mode of deprotonated $\mathrm{S}-\mathrm{O}(\mathrm{H})$ and carboxylate functional groups [35], Raman spectra of the composites provided with clear, fingerprint-like evidence for the exclusive production of double deprotonated cysteine sulfenic acid anions fixed among the layers of CaAl-LDH.

In our view, the changes observed in the oxidation products on altering the solvent is due to the changes of hydration/dehydration state of the interlayer gallery. Water is an integral part of an LDH, attached to the wall of the layers and to each other by secondary, probably mainly hydrogen bonds. On changing the solvent from water to methanol or acetone, at least partial replacement of the interlayer water molecules took place, thus, the immediate environment for the reaction was modified significantly, while all the other parameters (the LDH, reaction temperature, reaction time, the oxidant) remained unaltered. 


\section{Conclusions}

Applying CaAl-LDH as a molecular reactor, intercalated cysteinate anions could be oxidized with peracetic acid to various products depending on the solvent used. The formation of cystinate was experienced by using water as solvent, while double deprotonated cysteine sulfenic acid anions was observed in acetone solvent. The crucial contribution of the layered structure to the observed ways of transformations was evidenced.

Also, it was reasonable to assume that the hydration/dehydration state of the interlayer space modified by the solvents induced the significant shift in the oxidation pathways.

Author Contributions: Involved in the composite syntheses and oxidation reactions testing, Z.T. and T.N.H.; involved in the instrumental characterization part and in putting together the relevant part of the manuscript, C.P., Z.K., Á.K. and P.S.; supervised the project and wrote the first draft, G.V.; conceptualized the project and wrote the final version of the manuscript, I.P. All authors have read and agreed to the published version of the manuscript.

Funding: GINOP: GINOP-2.3.2-15-2016-00013, NKFIH: PD 128189.

Institutional Review Board Statement: Not applicable.

Informed Consent Statement: Not applicable.

Data Availability Statement: Data are available with the authors.

Acknowledgments: This work was supported by the Hungarian Government and the European Union through grant GINOP-2.3.2-15-2016-00013. The financial support is highly appreciated. One of us, G.V. thanks for the postdoctoral fellowship under the grant PD 128189.

Conflicts of Interest: The authors declare no conflict of interest.

\section{References}

1. Patel, R.N. Biocatalysis in the Pharmaceutical and Biotechnology Industries; CRC Press: Boca Raton, FL, USA, 2006; ISBN 9781420019377.

2. Deng, Z.; Hu, J.; Liu, S. Disulfide-Based Self-Immolative Linkers and Functional Bioconjugates for Biological Applications. Macromol. Rapid Commun. 2020, 41, 1-14. [CrossRef]

3. Gross, E.; Kastner, D.B.; Kaiser, C.A.; Fass, D. Structure of Ero1p, source of disulfide bonds for oxidative protein folding in the cell. Cell 2004, 117, 601-610. [CrossRef]

4. Sedõ, J.; Saiz-Poseu, J.; Busqué, F.; Ruiz-Molina, D. Catechol-based biomimetic functional materials. Adv. Mater. 2013, 25 , 653-701. [CrossRef] [PubMed]

5. Varga, G.; Timár, Z.; Csendes, Z.; Bajnóczi, É.G.; Carlson, S.; Canton, S.E.; Bagi, L.; Sipos, P.; Pálinkó, I. Building, characterising and catalytic activity testing of Co-C-protected amino acid complexes covalently grafted onto chloropropylated silica gel. J. Mol. Struct. 2015, 1090, 138-143. [CrossRef]

6. Sakimoto, K.K.; Zhang, S.J.; Yang, P. Cysteine-Cystine Photoregeneration for Oxygenic Photosynthesis of Acetic Acid from $\mathrm{CO}_{2}$ by a Tandem Inorganic-Biological Hybrid System. Nano Lett. 2016, 16, 5883-5887. [CrossRef]

7. Bafana, A.; Dutt, S.; Kumar, S.; Ahuja, P.S. Superoxide dismutase: An industrial perspective. Crit. Rev. Biotechnol. 2011, 31, 65-76. [CrossRef]

8. Pao-Chuan, H.; Chang-Yu, C. The Production of High-Activity Superoxide Dismutase (SOD) and Application in Methods of Both the Solid-State and Liquid-State Fermentation. U.S. Patent Application No. 11/383,496, 3 January 2008.

9. Martínez-Sernández, V.; Perteguer, M.J.; Hernández-González, A.; Mezo, M.; González-Warleta, M.; Orbegozo-Medina, R.A.; Romarís, F.; Paniagua, E.; Gárate, T.; Ubeira, F.M. Comparison of recombinant cathepsins L1, L2, and L5 as ELISA targets for serodiagnosis of bovine and ovine fascioliasis. Parasitol. Res. 2018, 117, 1521-1534. [CrossRef]

10. Gu, Y.; Yan, X.; Liu, W.; Li, C.; Chen, R.; Tang, L.; Zhang, Z.; Yang, M. Biomimetic sensor based on copper-poly(cysteine) film for the determination of metronidazole. Electrochim. Acta 2015, 152, 108-116. [CrossRef]

11. Liu, K.; Yuan, C.; Zou, Q.; Xie, Z.; Yan, X. Self-Assembled Zinc/Cystine-Based Chloroplast Mimics Capable of Photoenzymatic Reactions for Sustainable Fuel Synthesis. Angew. Chem. 2017, 129, 7984-7988. [CrossRef]

12. Tsujimura, M.; Odaka, M.; Nakayama, H.; Dohmae, N.; Koshino, H.; Asami, T.; Hoshino, M.; Takio, K.; Yoshida, S.; Maeda, M.; et al. A novel inhibitor for Fe-type nitrile hydratase: 2-Cyano-2-propyl hydroperoxide. J. Am. Chem. Soc. 2003, 125, 11532-11538. [CrossRef]

13. Poole, L.B.; Klomsiri, C.; Knaggs, S.A.; Furdui, C.M.; Nelson, K.J.; Thomas, M.J.; Fetrow, J.S.; Daniel, L.W.; King, S.B. Fluorescent and affinity-based tools to detect cysteine sulfenic acid formation in proteins. Bioconjug. Chem. 2007, 18, 2004-2017. [CrossRef] [PubMed] 
14. Gupta, V.; Carroll, K.S. Rational design of reversible and irreversible cysteine sulfenic acid-targeted linear C-nucleophiles. Chem. Commun. 2016, 52, 3414-3417. [CrossRef]

15. Sieracki, N.A.; Tian, S.; Hadt, R.G.; Zhang, J.L.; Woertink, J.S.; Nilges, M.J.; Sun, F.; Solomon, E.I.; Lu, Y. Copper-sulfenate complex from oxidation of a cavity mutant of pseudomonas aeruginosa azurin. Proc. Natl. Acad. Sci. USA 2014, 111, 924-929. [CrossRef] [PubMed]

16. Butterfield, D.A.; Perluigi, M.; Reed, T.; Muharib, T.; Hughes, C.P.; Robinson, R.A.S.; Sultana, R. Redox proteomics in selected neurodegenerative disorders: From its infancy to future applications. Antioxid. Redox Signal. 2012, 17, 1610-1655. [CrossRef] [PubMed]

17. Bettanin, L.; Saba, S.; Galetto, F.Z.; Mike, G.A.; Rafique, J.; Braga, A.L. Solvent- and metal-free selective oxidation of thiols to disulfides using $\mathrm{I}_{2}$ /DMSO catalytic system. Tetrahedron Lett. 2017, 58, 4713-4716. [CrossRef]

18. Darkwa, J.; Olojo, R.; Chikwana, E.; Simoyi, R.H. Antioxidant chemistry: Oxidation of L-cysteine and its metabolites by chlorite and chlorine dioxide. J. Phys. Chem. A 2004, 108, 5576-5587. [CrossRef]

19. Wang, X.; Stanbury, D.M. Direct oxidation of L-cysteine by $\left[\mathrm{Fe}^{\mathrm{III}}(\mathrm{bpy})_{2}(\mathrm{CN})_{2}\right]^{+}$and $\left[\mathrm{Fe}^{\mathrm{III}}(\mathrm{bpy})(\mathrm{CN})_{4}\right]^{-}$. Inorg. Chem. 2008, 47, 1224-1236. [CrossRef] [PubMed]

20. Böhm, M.; Tietze, A.A.; Heimer, P.; Chen, M.; Imhof, D. Ionic liquids as reaction media for oxidative folding and native chemical ligation of cysteine-containing peptides. J. Mol. Liq. 2014, 192, 67-70. [CrossRef]

21. Wei, M.; Shi, Z.; Evans, D.G.; Duan, X. Study on the intercalation and interlayer oxidation transformation of L-cysteine in a confined region of layered double hydroxides. J. Mater. Chem. 2006, 16, 2102-2109. [CrossRef]

22. Chen, Q.; Shi, S.; Liu, X.; Jin, L.; Wei, M. Studies on the oxidation reaction of L-cysteine in a confined matrix of layered double hydroxides. Chem. Eng. J. 2009, 153, 175-182. [CrossRef]

23. Varga, G.; Kukovecz, Á.; Kónya, Z.; Korecz, L.; Muráth, S.; Csendes, Z.; Peintler, G.; Carlson, S.; Sipos, P.; Pálinkó, I. Mn(II)-amino acid complexes intercalated in CaAl-layered double hydroxide-Well-characterized, highly efficient, recyclable oxidation catalysts. J. Catal. 2016, 335, 125-134. [CrossRef]

24. Varga, G.; Somosi, Z.; Kónya, Z.; Kukovecz, Á.; Pálinkó, I.; Szilagyi, I. A colloid chemistry route for the preparation of hierarchically ordered mesoporous layered double hydroxides using surfactants as sacrificial templates. J. Colloid Interface Sci. 2021, 581, 928-938. [CrossRef] [PubMed]

25. Benito, P.; Labajos, F.M.; Mafra, L.; Rocha, J.; Rives, V. Carboxylate-intercalated layered double hydroxides aged under microwavehydrothermal treatment. J. Solid State Chem. 2009, 182, 18-26. [CrossRef]

26. Cermelj, K.; Ruengkajorn, K.; Buffet, J.C.; O’Hare, D. Layered double hydroxide nanosheets via solvothermal delamination. J. Energy Chem. 2019, 35, 88-94. [CrossRef]

27. Zeleňák, V.; Vargová, Z.; Györyová, K. Correlation of infrared spectra of zinc(II) carboxylates with their structures. Spectrochim. Acta Part A Mol. Biomol. Spectrosc. 2007, 66, 262-272. [CrossRef]

28. Foley, S.; Enescu, M. A Raman spectroscopy and theoretical study of zinc-cysteine complexation. Vib. Spectrosc. 2007, 44, 256-265. [CrossRef]

29. Sugeta, H.; Go, A.; Miyazawa, T. S-S and C-S Stretching vibrations and molecular conformations of dialkyl disulfides and cystine. Chem. Lett. 1972, 1, 83-86. [CrossRef]

30. Xie, X.Y.; Zheng, W.J.; Bai, Y.; Liu, J. Cystine modified nano-sulfur and its spectral properties. Mater. Lett. 2009, 63, 1374-1376. [CrossRef]

31. Santhana Krishna Kumar, A.; Jiang, S.J. Preparation and characterization of exfoliated graphene oxide-L-cystine as an effective adsorbent of $\mathrm{Hg}(\mathrm{II})$ adsorption. RSC Adv. 2015, 5, 6294-6304. [CrossRef]

32. Timár, Z.; Varga, G.; Szabados, M.; Csankó, K.; Alapi, T.; Forano, C.; Prevot, V.; Sipos, P.; Pálinkó, I. Structural insight into the photoinduced $\mathrm{E} \rightarrow \mathrm{Z}$ isomerisation of cinnamate embedded in $\mathrm{ZnAl}$ and $\mathrm{MgAl}$ layered double hydroxides. J. Mol. Struct. 2020, 1219, 128561. [CrossRef]

33. Scuderi, D.; Bodo, E.; Chiavarino, B.; Fornarini, S.; Crestoni, M.E. Amino acid oxidation: A combined study of cysteine oxo forms by IRMPD spectroscopy and simulations. Chem. Eur. J. 2016, 22, 17239-17250. [CrossRef] [PubMed]

34. Dourado, A.H.B.; De Lima Batista, A.P.; Oliveira-Filho, A.G.S.; Sumodjo, P.T.A.; Cordoba De Torresi, S.I. L-cysteine electrooxidation in alkaline and acidic media: A combined spectroelectrochemical and computational study. RSC Adv. 2017, 7, 7492-7501. [CrossRef]

35. Noguchi, T.; Nojiri, M.; Takei, K.I.; Odaka, M.; Kamiya, N. Protonation structures of Cys-sulfinic and Cys-sulfenic acids in the photosensitive nitrile hydratase revealed by Fourier transform infrared spectroscopy. Biochemistry 2003, 42, 11642-11650. [CrossRef] [PubMed] 